\title{
INTEGRATED INFORMATION SYSTEMS FOR HIGHWAY MANAGEMENT
}

\author{
Yueh Liang ${ }^{1}$, Tsai-chu Wang ${ }^{2}$
}

\author{
Highway Bureau, Ministry of Transportation and Communications, ROC \\ 1. General Director; 2. Section Chief of Planning Department/joe0515@pchome.com.tw.
}

\begin{abstract}
The twenty-first century is a century that combines information and communication technology. Through upgrading information and communication technology, messages will be conveyed easily and, thus, affect road-user's life directly. The Taiwan Highway Bureau engaged in general censorship operation by combing GPS and GIS, and based on geograph information system of highway engineering facilities to intergrate whole engineering management systems in order to execute huge tasks such as construction and maintenance under limited resources.
\end{abstract}

Keyword: censorship operation, global positioning system (GPS), geographic information system (GIS).

\section{INTRODUCTION}

An integrated information system is the main direction for the Highway Bureau to develop and control her engineering quality. The motivation impetus Highway Bureau to work in this way can be classified into three reasons such as huge affairs, nature disasters and human behavior.

\subsection{Jurisdiction}

Based on the highway jurisdiction prospective, roadways in Taiwan are categorized into national roads, provincial roads, county roads, rural roads and exclusive roads. (See Table1)

Table 1. Coverage of Highway Bureau

\begin{tabular}{|l|c|r|r|r|r|}
\hline Items & $\begin{array}{c}\text { National } \\
\text { Roads }\end{array}$ & $\begin{array}{c}\text { Provincial } \\
\text { Roads }\end{array}$ & $\begin{array}{c}\text { County } \\
\text { Roads }\end{array}$ & $\begin{array}{r}\text { Rural } \\
\text { Roads }\end{array}$ & $\begin{array}{c}\text { Exclusive } \\
\text { Roads }\end{array}$ \\
\hline $\begin{array}{l}\text { Length } \\
\text { Km) }\end{array}$ & 548 & 4,376 & 2,451 & 12,467 & 390 \\
\hline Percent & 2.7 & 21.6 & 12.2 & 61.6 & 1.9 \\
\hline $\begin{array}{l}\text { Area } \\
\text { Hectare })\end{array}$ & $1,280.2$ & $5,254.6$ & $2,227.7$ & $6,332.9$ & 144.7 \\
\hline Percent & 8.2 & 35.5 & 14.5 & 40.9 & 0.9 \\
\hline
\end{tabular}

Source: Highway and Motor Transportation Statistics for 1998[1]

Highway Bureau takes the responsibility to manage provincial roads, county roads, and parts of rural roads. The Highway Bureau maintains most of roadways in Taiwan. The length of the provincial road is 4,376 kilometers that made up of $21.6 \%$ of total road mileage, while the county road is 2,451 kilometers that made up of $12.2 \%$ of total road mileage. The road area of provincial road is 5,529.7 hectares that occupies $35.5 \%$ of overall covered areas, and the county road is 2,246.6 hectares and $14.5 \%$ of covered areas. As for the highway facilities, bridges and tunnels are included. The number of the bridges is 10,084 and the sum length is about 300 kilometers. The number of tunnels is 269 , with length 30 kilometers.

\subsection{Nature Disasters}

The land area of Taiwan is only 36,000 square kilometers surrounding with ocean. Covered with $70 \%$ mountainous area extending in the north-south direction, Taiwan is left with limited plains. Due to the location, it is easy to be affected by natural disasters. When typhoon, earthquake or flood attacks Taiwan, highway facilities are often damaged or destroyed. For example, the Herbert typhoon in 1997 and the Chi-Chi earthquake in 1999 both caused tremendous losses in Taiwan's highways and bridges.

\subsection{Human Behavior}

Due to the overloading, over speeding trucks and illegal excavation of aggregate nearby rivers, roads and bridges dramatically suffer loss of service life.

To maintain bridges and roads takes huge amount of money and manpower. It is, thus, the Highway Bureau established efficient bridge management system, pavement management and other expert system to take actions in a proper manner.

Inflexibility in existing systems causes the waste of manpower, time and material resources. Inconsistency on information leads to confusion and uncertainty for users and decision-makers. The Highway Bureau is devoted to integrating the whole system and exerting the software system's construction of entire function.

\section{GOALS OF PLANNING}

Information systems would not develop efficiently if those could not be connected properly. According to the characteristic of user, the development of integrating management system will be divided into two major directions. 


\section{For Inner Decision-Making}

It is the combination of several professionals such as highway engineers, geotechnical engineers, traffic engineers and computer specialists. The major goal is to boost the efficiency of internal operations, provide the maker accurate information in advance, and help the maker to make proper decision for an immediate response. Those system included Construction and engineering management information system, disaster prevention system, bridge management system and pavement management system.

2. For servicing road-user

Providing service for the public is the basic creed of the Highway Bureau. Information that does not harm national security will be available to road-users in the near future. Travelers can receive up-to-date information to take actions ahead of time to avoid any inconveniences or hazards. Those systems included consulting system for road users, changeable sign system and highway disasters monitoring and warning System.

Through multiple-structure integrated information systems can reach their maximum efficiency. It includes two items described as follows:

1.Utilizing geographic information system of Highway

Facility as a center to combine the other existing System.( see Figure1).

2.Highway electronic maps as its backbone to combine database and method base via overlap with coordinates.

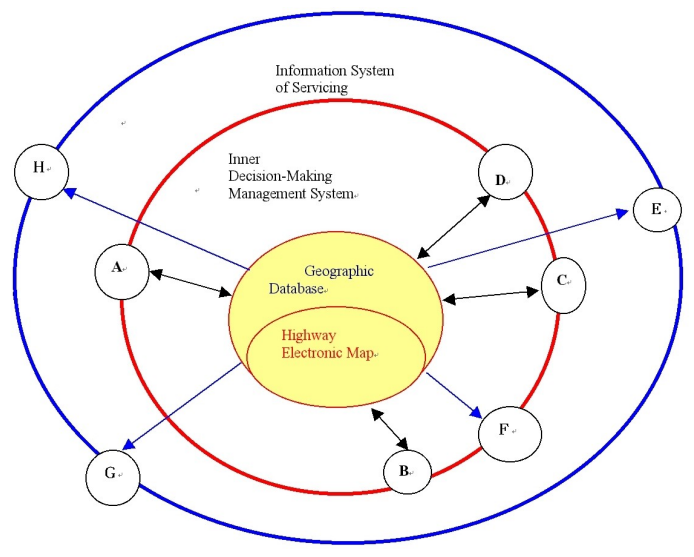

Figure 1. Structure for expert system in which A 、B、C、D、E、F、G and H represent different management subsystems

\section{METHODOLOGY}

\subsection{Combined GPS and GIS}

According to the Cause 33 of "Managerial Regulations of Highway's Construction and Maintenance", the goal of general censorship operation is to revise the route map and the information of highway's fundamental facility. The Highway Bureau applied and combined some techniques to improve the censorship operation such as GPS, GIS, Digital System and the Image System. Figure2 showed the structure of combing GPS and GIS used in censorship operation.

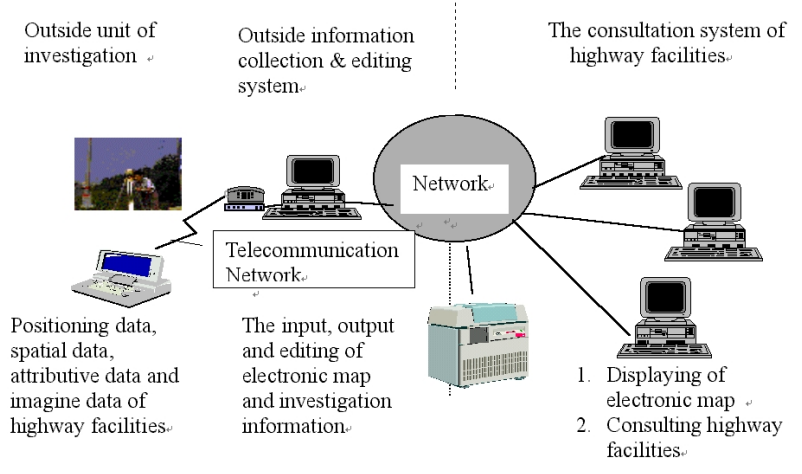

Figure 2. The structure of combing both GPS and GIS which were used in censorship operation.

The job of Highway censorship operation described as follows:

1.Scopes: provincial roads, county roads, and rural roads. The sum of road length is about 20.000

kilometers.

2.Highway facilities: the highway facilities could be classified 12 items, such as pavement, bridge, tunnel, pipe-drain, prevention, roadway condition, byway, at-grade railroad intersection, overhead crossing, steep slope, and sharp curve, etc.

The third highway censorship operation began in 1996. It predicted to be completed in 2002.

\subsection{Problem Identification}

These existing expert systems work in different platform and operation environment. These systems should take a lot money and manpower to maintain it in order to keep a good work. But such systems face serious problems that are urgent to be solved. Reviewed those problem and could be classified as follow.

1.The forms of several information systems are different, so the data cannot conversion and renewal within each other. To unify all forms is ranked the priority.

2.Deployed in software (platforms and software interface) and hardware is not optimal, so the function cannot develop well.

3.Participators who engaged in different engineering field can not realized the demand of system function such as static function and analyzed function, and the software engineer may lack of engineering judgement in the beginning of establishing systems. Communication between two professionals needs to be strengthened.

4. The accuracy of domestic maps is not unified. The discrepancy is large, so it is a difficult task put precision under control.

\subsection{Integration}

\subsubsection{Data Collection}

Data collection is a main stage for system construction and integration. A whole system is not 
only providing users a function for data edit or search, but provide static and analyze function for decision-maker. Beginning the process of data collection, stored data in database and method base separately. Database included attribute data, spatial data and imagine data. All data get from censorship operation. Method data included all documents about engineering techniques and experience such as design sketch, construction sketch, completed sketch and epitome sketch of roads, bridges, tunnels, and other highway facilities. Method bases recorded all engineering experience, analyze disasters, and provide the information for decision-makers when accidents occur.

\subsubsection{Establish a Relationship Table}

After identified problems, the Highway Bureau is currently investigating the linkage among whole systems. Built up a relationship table to connect database and method base via coordinate. The platform of could get the data form database and method base in the same time and transfer them into information available.

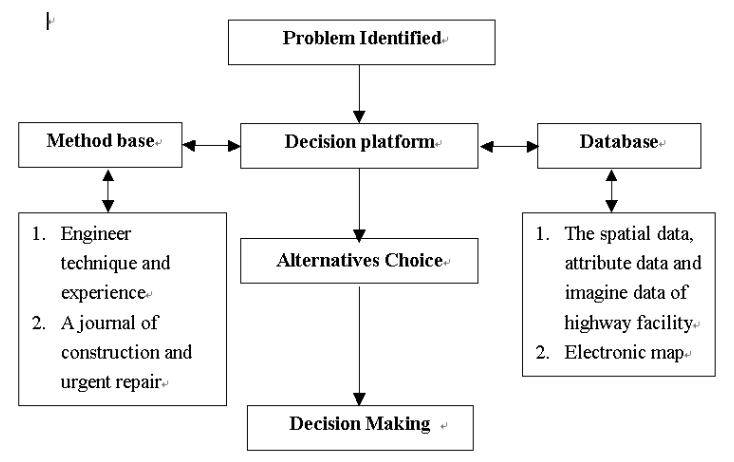

Figure 3: Integrated system structure

\subsubsection{Periods Controlled}

Set up periods to achieved percentage of scheduled progress of system integration. According to the process of term control, there are classified into preparation stage, integration stage and function expansion stage.

1. Preparation stage (from 1992 to 2001).

The data management stage is to construct the fundamental system that can keep a basic operation, and to collect relevant data continuously. The major work is to set up database.

2 Integrated stage (from 1999 to 2002).

The Highway Bureau engaged in collecting and upgrading data continuously. In the meantime, enhanced analysis functions to the system. The major structure is based on geographical information system of highway facility. The other tasks in this stage are described as follows.

(1) Integration of database, method base and sharing resources. The major task is to combine the coordinate, the name of a road and pile number, and to connect highway electronic map.

(2) Completion of network and enhancement of data continuously.

(3) In accordance with the issuance of national coordinate system in March 1998, highway electronic maps coordinate is converted from
GRS67 to GRS80.

(4) Integrating contour line.

3. Function expansion stage (from 2000 to 2003).

The major task in this stage is to connect database, method base and decision platform. Another is to promote system function and to complete complicated electronic highway networks. Others are described as followed. First, renew manipulation environment and work platform. Second, imputed and integrated of other expert systems. Third, enhancement of system functions and development of forward real time handling function.

The Highway Bureau will strengthen automatic detecting car (ARAN) to collect and analysis data by equipped GPS, INS, POS/LV (Position Orientation System for Land Vehicles) and photon system. Through radio carrier, the road's situation and disaster's news are loaded to the Highway Bureau in time. Overlapped with highway electronic map and contour line map in geographic information system, decision-makers are fully informed.

\section{EXPECTED ACHIEVEMENTS}

Through coordinates the editing system can position various highway facilities and connect to the electronic map. All information could be display and supported from consulting sub-system after completed system integration.

\subsection{Edit function}

The editing system set up 12 charts aimed at organizing 12 highway facilities. By positioning various routes and highway facilities, conduct highway electronic map and then convert to 2-TM coordinate. Another function is that edits all spatial, attribute and imagines data and store in database. Figure 4 showed the process of editing Kuan-do Bridge. By down-loaded WGS-84 coordinates of Kuando Bridge to display the spatial location on electronic highway map, then the system will show a form to remind editors to fill all blank. These data could be connected via coordinate. Finally, keying all relative data such as the upper structure, pier structure, net width, number of spans, the period of construction, the pile number of starting place, the name of rivers and so on.

In order to present the bridge in a full view, system provided a function, hot-link, to link pictures that revealed the different parts of the bridge's structure. This function has been used widely in rescue after the Chi-Chi earthquake.

\subsection{Consulting function}

Consulting function provided users two ways to search data. There are word consulting and 


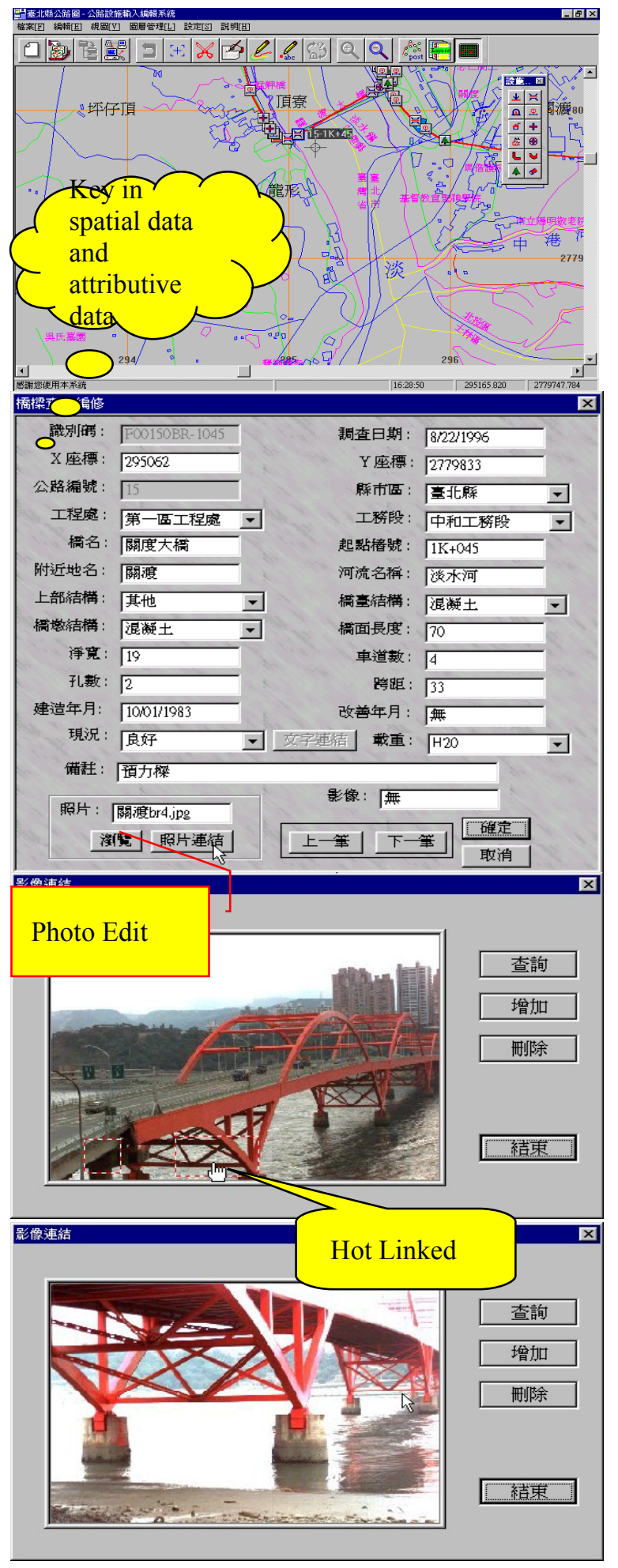

Figure 4. Editing Kuan-do Bridge $\square$ data
Bridge. The first step is to choice objectbridge. Then set the consulting items such as the bridge is located on provincial highway No.3 in the Taipei County, and its length is over 100 meters. There are three bridges can fit three qualified after searched all data. The Haw-chang Bridge is the one of them.

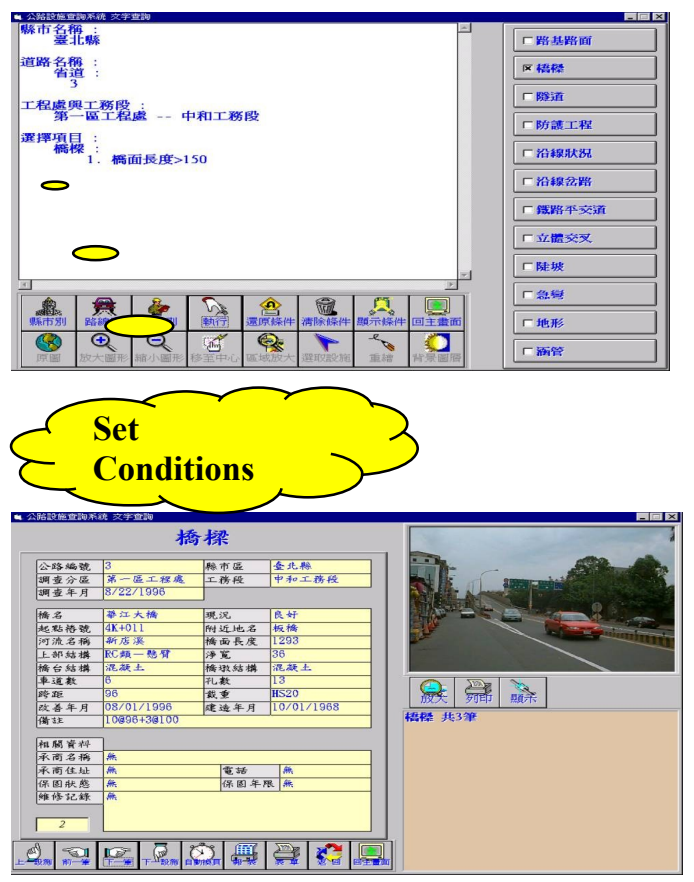

Figure 5. Search Haw-chang Bridge

\subsubsection{Figure Consulting}

The junior engineers may not know the location of bridges exactly, but they can find out the necessary information through the figure consulting. Figure 6 is an example to search Dai-han Bridge. Firstly, set the bridge item. Second, zoning area's magnifying to reveal the relation between bridges and routes. Then open the partial chart layer of digital map and overlap with it. Finally, click the right key twice, the attribution information of the Daihan Bridge will be revealed.

figure consulting.

\subsubsection{Word Consulting}

For the senior engineers, they have better understanding on the jurisdiction of bridges. They can key in the bridge's name and get the related information directly. As for uncertain bridges, the relative terms are used. Engineers can set the terms directly such as the length of bridges, the roads, and narrow the consulting category. By this way, engineers can find out the necessary information soon. Figure 5 is a sample for search Haw-chang 


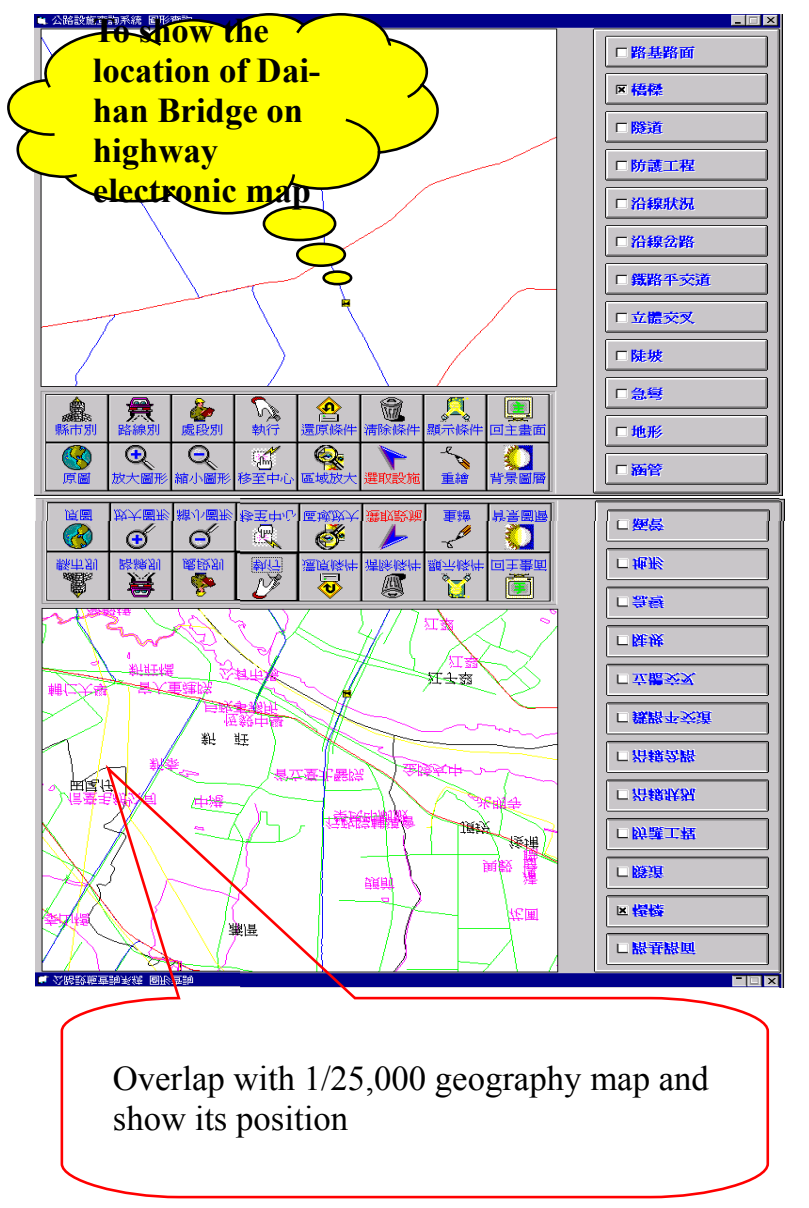

Figure 6. Searching for the position of Dai-han Bridge

\subsubsection{Analysis Function}

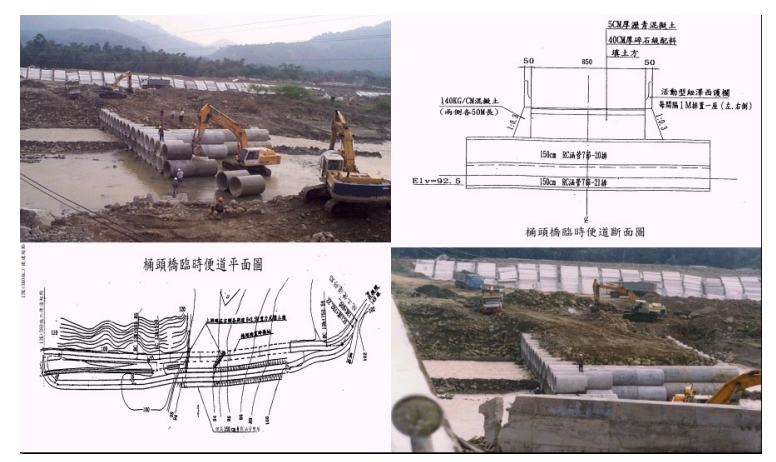

Figure 7. Simulated systems recording all engineering sketches about temporary road of Tonto Bridge.

In future, systems will not only provide edit and consults function to user. Systems could provide alternatives to decision-makers and managers through decision platform that combined database and method base. The highway Bureau expected to count the amount of earth, estimate engineering expense, mark out the boundary of disaster area, and assign the machine, material and facilities from systems directly. Figure 7 and Figure 8 simulated systems recording all engineering sketches about temporary road of Ton-to Bridge and I-chuan Bridge. The platform could combine such data and attribute data, and then transfer them into optimal information available.

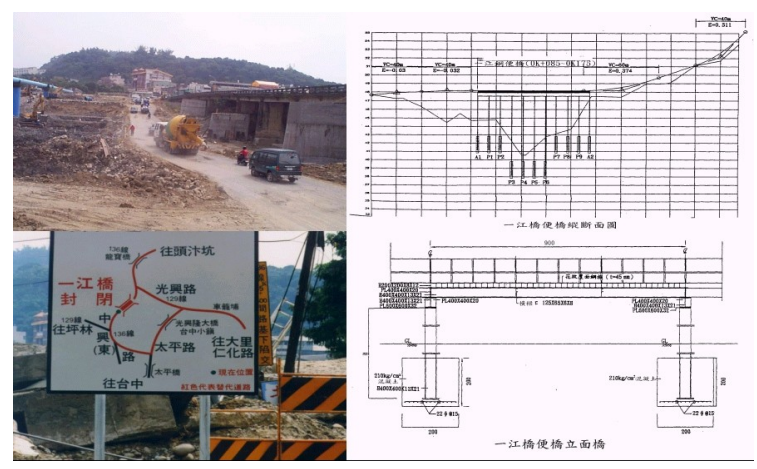

Figure 8. Simulated systems recording all engineering sketches about temporary road of I-chuan Bridge.

\section{CONCLUSIONS}


"Expeditiousness" and "efficiency" are tendency of government reform in the $21^{\text {th }}$ century. Restrained by limited resources, systems integration is a good way to reach such goals. System functions are utilized to record, store and update all engineering experience, techniques and methods. The system can be also used to train junior engineers and provide managers full information or alternatives to make appropriate decisions in time. Added value is to release sufficient information to users such as road-users, factory owners, enterprise and industry.

\section{REFERENCES}

[1] Highway and Motor Transportation Statistics for 1998.

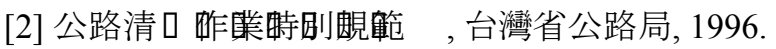

[3] 張瑞剛, GPS 衛星測量學, 声雲文化有限公司, 1996.

[4] 陳晉源、王在莒,"GPS+GIS 於公路工程設施之應用", 道路新進技術發展與應用, 台灣營建研究院營建系列 叢書, pp.141-159,1999.

[5] 林志棟、張家瑞、洪境聰、張其教, ”舖面檢測車在舖 面維護管理之應用”, 道路新進技術發展與應用, 台灣營 建研究院營建系列叢書, pp.37-75, 1999.

[6] 施保旭, 地理資訊系統, 儒林圖書公司, 1997.

[7] 王在莒、張瑞剛、管麗琴、黃文魁, 'GPS 與 GIS 於公 路普口昡磼畍”, 第十六屆測量學術及應用研討會, pp.36-43, 1997.

[8] 姚乃嘉, “台灣省公路局橋梁管理系統發展現況”, 台 灣省公路局段長研習會論文, 1998.

[9] 葉昭雄, “921 地震公路局轄管公路橋梁損壞情形報 告 " , Taiwan Highway Engineering Vol.26 No.5 November, pp.2-36, 1999.

[10] 內政部營建署, 地面測量法數，㽘畈則 量作業手冊, 1996. 